\title{
Nitrous oxide emissions from managed grassland: a comparison of eddy covariance and static chamber measurements
}

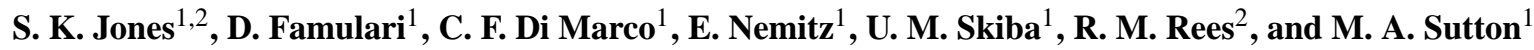 \\ ${ }^{1}$ Centre for Ecology and Hydrology, Edinburgh, Bush Estate, Penicuik, Midlothian EH26 QB, UK \\ ${ }^{2}$ Scottish Agricultural College, King's Buildings, West Mains Road, Edinburgh, EH9 3JG, UK \\ Received: 16 December 2010 - Published in Atmos. Meas. Tech. Discuss.: 17 February 2011 \\ Revised: 8 September 2011 - Accepted: 23 September 2011 - Published: 17 October 2011
}

\begin{abstract}
Managed grasslands are known to be an important source of $\mathrm{N}_{2} \mathrm{O}$ with estimated global losses of $2.5 \mathrm{Tg} \mathrm{N}_{2} \mathrm{O}$ $\mathrm{Nyr}^{-1}$. Chambers are to date the most widely used method to measure $\mathrm{N}_{2} \mathrm{O}$ fluxes, but also micrometeorological methods are successfully applied. In this paper we present a comparison of $\mathrm{N}_{2} \mathrm{O}$ fluxes measured by non-steady state chambers and eddy covariance (EC) (using an ultra-sonic anemometer coupled with a tunable diode laser) from an intensively grazed and fertilised grassland site in South East Scotland. The measurements were taken after fertilisation events in 2003, 2007 and 2008. In four out of six comparison periods, a short-lived increase of $\mathrm{N}_{2} \mathrm{O}$ emissions was observed after mineral $\mathrm{N}$ application, returning to background level within 2-6 days. Highest fluxes were measured by both methods in July 2007 with maximum values of $1438 \mathrm{ng}$ $\mathrm{N}_{2} \mathrm{O}-\mathrm{N} \mathrm{m}^{-2} \mathrm{~s}^{-1}$ (EC) and $651 \mathrm{ng} \mathrm{N}_{2} \mathrm{O}-\mathrm{N} \mathrm{m}^{-2} \mathrm{~s}^{-1}$ (chamber method). Negative fluxes above the detection limit were observed in all comparison periods by EC, while with chambers, the recorded negative fluxes were always below detection limit. Median and average fluxes over each period were always positive. Over all 6 comparison periods, $69 \%$ of $\mathrm{N}_{2} \mathrm{O}$ fluxes measured by EC at the time of chamber closure were within the range of the chamber measurements. $\mathrm{N}_{2} \mathrm{O}$ fluxes measured by EC during the time of chamber closure were not consistently smaller, neither larger, compared to those measured by chambers: this reflects the fact that the different techniques integrate fluxes over different spatial and temporal scales. Large fluxes measured by chambers may be representing local hotspots providing a small contribution to the flux measured by the EC method which integrates over a larger area. The spatial variability from
\end{abstract}

Correspondence to: S. K. Jones

(stephanie.jones@sac.ac.uk) chamber measurements was high, as shown by a coefficient of variation of up to $139 \%$. No diurnal pattern of $\mathrm{N}_{2} \mathrm{O}$ fluxes was observed, possibly due to the small diurnal variations of soil temperature. The calculation of cumulative fluxes using different integration methods showed EC data provide generally lower estimates of $\mathrm{N}_{2} \mathrm{O}$ emissions than chambers.

\section{Introduction}

At the global scale, soils are the most important source of the greenhouse gas nitrous oxide $\left(\mathrm{N}_{2} \mathrm{O}\right)$, with an estimated emission of $9.5 \mathrm{Tg} \mathrm{N}_{2} \mathrm{O}-\mathrm{N} \mathrm{yr}^{-1}$ (65\% of total global emissions), $1 \mathrm{Tg}$ of which originates from temperate grasslands (IPCC, 2001). The two mechanisms principally responsible for $\mathrm{N}_{2} \mathrm{O}$ emissions from soils are the microbial processes nitrification and denitrification which are mainly controlled by oxygen supply (and hence soil moisture), temperature, the availability of nitrogen and mineralizable carbon, as well as soil $\mathrm{pH}$ and soil microbial community (e.g. Granli and Bockman, 1994; Smith et al., 1998; Dobbie et al., 1999). Emissions are highly variable in space and time due to small scale changes of substrates and oxygen supply in the soil as well as changing environmental and management conditions over time. In temperate climates $\mathrm{N}_{2} \mathrm{O}$ emissions have been shown to be largely event driven with rainfall, water filled pore space (WFPS) and nitrogen fertilisation being critical factors (e.g. Flechard et al., 2005, 2007; Jones et al., 2007). Annual emissions of $\mathrm{N}_{2} \mathrm{O}$ from agricultural land, especially grazed grassland, are therefore difficult to quantify and the uncertainty surrounding national inventories and global estimates of agricultural $\mathrm{N}_{2} \mathrm{O}$ emissions is still high (Grant and Pattey, 2003; Dejardins, 2004; Flechard et al., 2007).

Published by Copernicus Publications on behalf of the European Geosciences Union. 
All data sets used to define IPCC $\mathrm{N}_{2} \mathrm{O}$ emission factors, which are used for official estimates of annual $\mathrm{N}_{2} \mathrm{O}$ fluxes from agricultural ecosystems, originate from manually operated static chamber measurements (Bouwmann, 1996; IPCC, 1997). Manually operated static chambers are fairly inexpensive, do not require power (unless a fan is used) and are simple to operate. They provide valuable information comparing different treatments or assessing the spatial variability (e.g. Clayton et al., 1994; Velthof et al., 1996; Jones et al., 2007). However, their coverage is limited over space and time. The cover area per measurement is usually less than $1 \mathrm{~m}^{2}$ and measurements are rarely taken more than once per day. Thus, this method is not well suited to describe daily variations or short-lived emission pulses induced by events such as rainfall, fertilization, re-wetting of dry soil and freeze-thaw. It is therefore not surprising the uncertainty of annual flux estimates from manually operated chambers is as high as $50 \%$ due to spatial and temporal variability (Flechard et al., 2007). Further downsides of chambers are that they are intrusive, as they have to be inserted into the soil and this may temporarily change $\mathrm{C}$ and $\mathrm{N}$ cycling by disturbing the soil and cutting roots; their presence in the field may affect the grazing behaviour of animals, and they modify the environmental conditions (wind, temperature) during the measurement (e.g. Ambus and Christensen, 1994; Davidson et al., 2002). Furthermore, it has been shown that static chambers potentially underestimate fluxes if no fan is used to mix the chamber headspace (Pumpanen et al., 2004; Christiansen et al., 2011).

An alternative, less disruptive approach in measuring fluxes at high time resolution at field scale level is offered by micrometeorological techniques. These methods require a uniform surface to be investigated, wind, temperature and gas concentrations at one or more points above the soilvegetation surface, using high sensitivity gas analysers. The area over which a flux can be integrated ranges from 0.01$1 \mathrm{~km}^{2}$, depending on the height of the sampling tower. However, this requires a uniform surface, which in many agricultural ecosystems may be a limitation. Further downsides of micrometeorological techniques applied to $\mathrm{N}_{2} \mathrm{O}$ are that they are more expensive and require higher expertise than static chambers. The most widely used micrometeorological technique for $\mathrm{N}_{2} \mathrm{O}$ flux measurements is the eddy covariance (EC) method, but also the Relaxed Eddy Accumulation (REA) and the flux gradient method have been applied to $\mathrm{N}_{2} \mathrm{O}$ emission measurements (see e.g. Skiba et al., 1996; Pattey et al., 2006; Desjardin et al., 2010). $\mathrm{N}_{2} \mathrm{O}$ has been measured successfully in agricultural ecosystems by EC since the development of suitable high frequency fast response $\mathrm{N}_{2} \mathrm{O}$ analysers, such as lead salt tunable diode lasers (e.g. Smith et al., 1994; Wienhold et al., 1995; Fowler et al., 1995; Laville et al., 1999; Di Marco et al., 2004) and more recently, quantum cascade lasers (e.g. Neftel et al., 2007; Kroon et al., 2010).
The objectives of this paper are to assess the suitability of manual chambers and eddy covariance as methods for measuring $\mathrm{N}_{2} \mathrm{O}$ emissions at the field scale, both in terms of instantaneous fluxes in response to trigger events, and in terms of time-integrated (cumulative) fluxes over several weeks with a view to deriving emission factors, contributing to the improvement of national inventories.

We present a comparison of $\mathrm{N}_{2} \mathrm{O}$ flux data sets measured by manually operated non-steady state chambers and eddy covariance technique from an intensively grazed and fertilised grassland site in the South East of Scotland. The measurements were taken after six mineral $\mathrm{N}$ fertilisation events in 2003, 2007 and 2008 with comparison periods lasting between 3 and 29 days.

\section{Materials and methods}

\subsection{Site description}

The Easter Bush measurement site is located in a rural area $10 \mathrm{~km}$ south of Edinburgh, Scotland UK $\left(3^{\circ} 12^{\prime} \mathrm{W}, 55^{\circ} 52^{\prime} \mathrm{N}\right.$, $190 \mathrm{~m}$ a.s.l.). The site consists of two intensively-managed grassland fields of approximately 5 ha each, here referred to as "South" and "North" fields (see Fig. 1, for a more detailed description of the site refer to Milford et al., 2001). The equipment for eddy covariance measurements was situated on the boundary between the two fields. This enabled eddy covariance flux measurements from the South field in south westerly wind and from the North field in north easterly wind, along the prevailing wind direction. Over the years 2003-2008, the fields received mineral fertiliser of an average $183 \mathrm{~kg} \mathrm{Nha}^{-1} \mathrm{yr}^{-1}$ split into three to four fertiliser applications per year. Simultaneous measurements between EC and chamber methods of $\mathrm{N}_{2} \mathrm{O}$ fluxes were made at fertilisation events on six occasions (see Table 1). In 2003, fourteen chambers were placed in the South field while in 2007 and 2008 four chambers were placed in the South field and four chambers in the North field. Both fields were continuously grazed at an average grazing intensity of 0.70 livestock units $\mathrm{ha}^{-1}$, where one live stock unit (LSU) corresponds to a dairy cow with a live weight of $600 \mathrm{~kg}$ (Farm management Handbook SAC, 1995). In our study, grazing animals consisted of sheep ( $60 \mathrm{~kg}$ live weight, LSU 0.1), lambs (5-45 kg live weight, LSU 0.04) and occasionally heifers in calve ( $450 \mathrm{~kg}$ live weight, LSU 0.75). The soil was an imperfectly drained Macmerry soil series, Rowanhill soil association (eutric cambisol) with a $\mathrm{pH}\left(\right.$ in $\mathrm{H}_{2} \mathrm{O}$ ) of 5.1 and a clay fraction of $20-26 \%$. The main grass species was Italian ryegrass (Lolium perenne). The average annual rainfall (20032008) was $994 \mathrm{~mm}$ and the annual mean temperature was $9.04{ }^{\circ} \mathrm{C}$ with a maximum monthly mean of $16.8^{\circ} \mathrm{C}$ occurring in July 2003 and a minimum of $3.5^{\circ} \mathrm{C}$ in February 2005. 


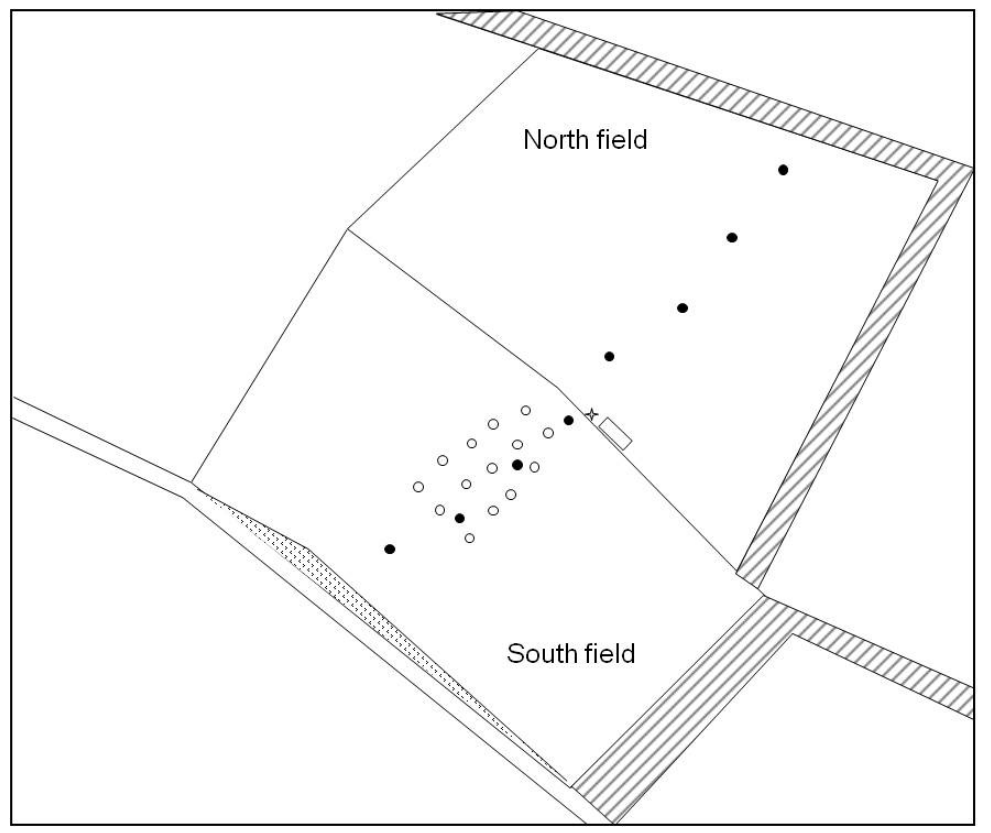

- Chamber positions 2003

- Chamber positions $2007 / 2008$

$\downarrow$ Sonic / TDL inlet

Cabin / TDL

Woodland

Hedge

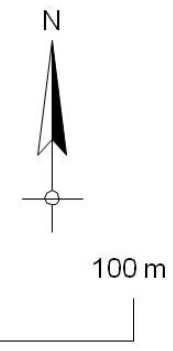

Fig. 1. Site diagram of the study field Easter Bush, showing locations of static chambers in the South and North field in 2003 and 2007/2008, micrometeorological mast (eddy covariance inlet and sonic position) and cabin (containing TDL) on the boundary of the two fields and prevailing wind directions.

Table 1. Overview of comparison periods of eddy covariance and chamber $\mathrm{N}_{2} \mathrm{O}$ flux measurements, fertiliser application dates, amount of $\mathrm{N}$ applied, average air and soil temperature $\left(T_{\text {air }}, T_{\text {soil }}\right)$, average soil water content (SWC), average water filled pore space (WFPS) and total rainfall.

\begin{tabular}{|c|c|c|c|c|c|c|c|c|}
\hline Comparison period & $\begin{array}{r}\text { Duration } \\
\text { [days] }\end{array}$ & Fertilisation date & $\begin{array}{l}\mathrm{N} \text { fertiliser input } \\
{\left[\mathrm{kg} \mathrm{N} \mathrm{ha}^{-1}\right]}\end{array}$ & $\begin{array}{r}T_{\text {air }} \\
{\left[{ }^{\circ} \mathrm{C}\right]}\end{array}$ & $\begin{array}{r}T_{\text {soil }(7.5 \mathrm{~cm})} \\
{\left[{ }^{\circ} \mathrm{C}\right]}\end{array}$ & $\begin{array}{r}\mathrm{SWC}(7.5 \mathrm{~cm}) \\
{[\%]}\end{array}$ & $\begin{array}{r}\text { WFPS }(7.5 \mathrm{~cm}) \\
{[\%]}\end{array}$ & $\begin{array}{r}\text { rain } \\
{[\mathrm{mm}]}\end{array}$ \\
\hline 11.6.-13.6. 2003 & 3 & 10.6. 2003 & 48 & 14.9 & 13.8 & 35 & 66 & 2 \\
\hline 10.5.-7.6. 2007 & 29 & 16.5. 2007 & 51.75 & 10.3 & 10.9 & 41 & 75 & 120 \\
\hline 10.7.-27.7. 2007 & 18 & 11.7. 2007 & 51.75 & 13.5 & 14.0 & 45 & 84 & 65 \\
\hline 14.5.-26.5. 2008 & 13 & 13.5. 2008 & 51.75 & 10.5 & 11.8 & 36 & 68 & 18 \\
\hline
\end{tabular}

\subsection{Chamber measurements of $\mathrm{N}_{2} \mathrm{O}$ fluxes}

Static chambers, each covering an area of $0.1256 \mathrm{~m}^{2}$, were used for the enclosure technique. Each chamber consisted of a $0.2 \mathrm{~m}$ long PVC ring (diameter $0.4 \mathrm{~m}$ ) with a $0.045 \mathrm{~m}$ wide PVC flange fitted to the outward facing end (Clayton et al., 1994). The ring was inserted into the soil to approx. $3 \mathrm{~cm}$ depth giving a headspace volume of 21.41. Chambers were closed for $60 \mathrm{~min}$ with an aluminium lid fitted with draft excluder. Samples of $200 \mathrm{ml}$ were collected by syringe into Tedlar bags at the beginning and at the end of the closure time through a three-way tap which was fitted into the lid. The syringe was flushed three times before sampling in order to mix the chamber air. In the laboratory, samples were transferred to glass vials and analyzed for $\mathrm{N}_{2} \mathrm{O}$ using a Hewlett Packard 5890 series II gas chromatograph (Agilent Technologies, Stockport, UK), fitted with an electron capture detector (detection limit for $\mathrm{N}_{2} \mathrm{O} 33 \mathrm{ppbV}$ ). Chamber closure and gas sampling were carried out between 10:00 h and 12:00 h. Fluxes were calculated as

$F=\frac{\Delta C}{\Delta t} \times \frac{V}{A}$

where $V$ and $A$ are the volume and surface area of the chamber, $\Delta C$ is the difference in the $\mathrm{N}_{2} \mathrm{O}$ concentration between the start and the end gas sample, and $\Delta t$ is the closing time, so $\Delta C / \Delta t$ is the slope of the gas concentration change with time. Repeated linearity tests, taking samples every $15 \mathrm{~min}$ 
over $2 \mathrm{~h}$, were carried out prior to, as well as in between measurement campaigns, showing a linearity of up to $120 \mathrm{~min}$ with an average $r^{2}=0.96$. The estimated detection limit for $\mathrm{N}_{2} \mathrm{O}$ fluxes measured by the chambers in this campaign was $12 \mathrm{ng} \mathrm{N}_{2} \mathrm{O}-\mathrm{N} \mathrm{m}^{-2} \mathrm{~s}^{-1}$. The chambers were removed every two weeks to reduce the chamber effect on the vegetation and soil and allow free grazing. Chambers were re-positioned at least $24 \mathrm{~h}$ before measurement, to avoid the influence of the soil disturbance on $\mathrm{N}_{2} \mathrm{O}$ production. The grass inside the chambers was always accessible to the animals for grazing, apart from the $1 \mathrm{~h}$ period during which chambers were closed for the $\mathrm{N}_{2} \mathrm{O}$ measurements. Grazing maintained a canopy height that was always lower than the chamber height $(20 \mathrm{~cm})$ and therefore chambers were operational throughout the inter-comparison periods.

\subsection{Eddy-covariance measurements of $\mathrm{N}_{2} \mathrm{O}$ fluxes}

The eddy covariance flux was calculated as the covariance between the $\mathrm{N}_{2} \mathrm{O}$ concentration $(\chi)$ and the vertical component of the wind speed $(w)$ as:

$F_{\chi}=\overline{\chi^{\prime} w^{\prime}}$.

$\chi^{\prime}$ and $w^{\prime}$ represent the fluctuations around the mean components of concentration and vertical wind speed respectively (see e.g. Kaimal and Finnigan, 1994; Stull, 1988). In order to capture the small scale eddy contribution to the flux, fast response sensors are required to measure the fluctuations in concentrations and wind speed (depending on the height above the surface: typically for grasslands at 5 to $20 \mathrm{~Hz}$ ). This is achieved using ultra-sonic anemometers for components of turbulence (see e.g. Kaimal and Gaynor, 1991), and by chemical analysers that are able to sense an increasing variety of scalar concentrations at fast rates, such as Tunable Diode Laser absorption spectrometers (TDL) in the case of $\mathrm{N}_{2} \mathrm{O}$ (see e.g. Zahniser et al., 1995; Fowler et al., 1995). A fast response ultrasonic anemometer (model USA-1, METEK GmbH, Elmshorn, Germany) was used to measure the three components of the wind at a frequency of $10 \mathrm{~Hz}$. It was mounted on a $2.35 \mathrm{~m}$ mast located at the edge between the two fields, with a fetch of approximately $250 \mathrm{~m}$ in the prevailing wind direction. The $\mathrm{N}_{2} \mathrm{O}$ concentration was measured by a TDL (Aerodyne Research Inc., Billerica, MA, USA) located in a monitoring cabin on the field. An inlet line of Dekabon tubing, 1/4" OD was placed underneath the transducers of the sonic anemometer, drawing air to the TDL sampling cell at a rate of $151 \mathrm{~min}^{-1}$. The TDL was operated at a frequency of 5 to $7 \mathrm{~Hz}$ and was tuned to use an $\mathrm{N}_{2} \mathrm{O}$ adsorption feature at a wave number of $2009.4 \mathrm{~cm}^{-1}$. Daily manual calibrations were applied using an ambientlevel standard gas mixture of $320 \mathrm{ppbV}$, cross-calibrated with a NOAA standard mixture. The detection limit of the TDL was estimated to be $1 \mathrm{ppbV}$ at $1 \mathrm{~s}$ averaging time.

A custom made LabView (National Instruments Inc.) program acquired the raw data from the sonic anemometer and the TDL, and calculated online fluxes for each half hour period. A double coordinate rotation was applied to the raw data, offline concentrations were calibrated against the standard gas concentration and were reanalysed to correct for density fluctuations caused by water vapour fluxes according to the method by Webb-Pearman-Leuning (see Webb et al., 1980). The temperature fluctuation component of this WPL correction was ignored as the inlet line was long enough to establish temperature equilibrium. The time-lag between the measurement of the vertical wind component and $\mathrm{N}_{2} \mathrm{O}$ concentration was determined from the absolute maximum in their cross-correlation within a pre-defined window ( 0.7 to $1.7 \mathrm{~s}$ on average). According to recent findings (e.g. Taipale et al., 2010), this practice can overestimate the flux (both negative and positive fluxes) if a noisy sensor is used: since that was our case (especially for the 2008 data) we also calculated the fluxes with a fixed time lag (using clear emission fluxes time lags derived from the maximum cross correlation function) and compared the two outcomes.

For a $30 \mathrm{~min}$ averaging period the detection limit of the $\mathrm{N}_{2} \mathrm{O}$ flux measurement was estimated at $11 \mathrm{ng} \mathrm{N}_{2} \mathrm{O}-\mathrm{N}$ $\mathrm{m}^{-2} \mathrm{~s}^{-1}$ by flushing zero- $\mathrm{N}_{2} \mathrm{O}$ air through the system and measuring the flux. In some instances, the lead salt laser instability affected the concentration measurements, creating variations that do not reflect the real atmospheric turbulence (see also Di Marco, 2005). In order to avoid instrumental artefacts, we calculated the flux detection limit according to the method by Wienhold (Wienhold et al., 1994) for each half hourly flux. The average detection limit ranged between $12.3 \mathrm{ng} \mathrm{N}_{2} \mathrm{O}-\mathrm{N} \mathrm{m}^{-2} \mathrm{~s}^{-1}$ and $33.6 \mathrm{ng} \mathrm{N}_{2} \mathrm{O}-\mathrm{N} \mathrm{m}^{-2} \mathrm{~s}^{-1}$ across the measurements campaigns. The events where the flux value was below detection limit were discarded. In order to investigate high frequency losses due to signal attenuation, we applied the Horst formula (see Horst, 1997) which resulted in an average flux loss of $10 \%$; this result was confirmed by applying a spectral correction on the ogives (as in Ammann et al., 2006) on selected flux events. The ogive analysis applied to all fluxes, by comparison with the sensible heat fluxes curves was used in addition as a rejection criterion, to visually exclude flux values that presented irregularities.

We applied further filters to the data. (i) A spike removal routine was embedded in the re-analysis custom made program (ii) a stationarity filter (see Affre et al., 2000) was applied to the $\mathrm{N}_{2} \mathrm{O}$ flux values (iii) the variances of the half-hourly concentrations of $\mathrm{N}_{2} \mathrm{O}$ were used to flag periods that presented anomalous variation of concentration. Due to instruments downtime, data coverage for the EC fluxes were: $80 \%$ in June 2003, $82 \%$ in March 2007, $90 \%$ in May 2007, 76\% in June 2007, $30 \%$ in May 2008 and $37 \%$ in July 2008. The remarkable difference between data coverage percentages between 2007 and 2008 is explained by the different lead salt laser source: at the end of 2007 it had to be changed, and the replacement laser diode proved a lot more unstable. Rejection of $\mathrm{N}_{2} \mathrm{O}$ fluxes due to quality control 

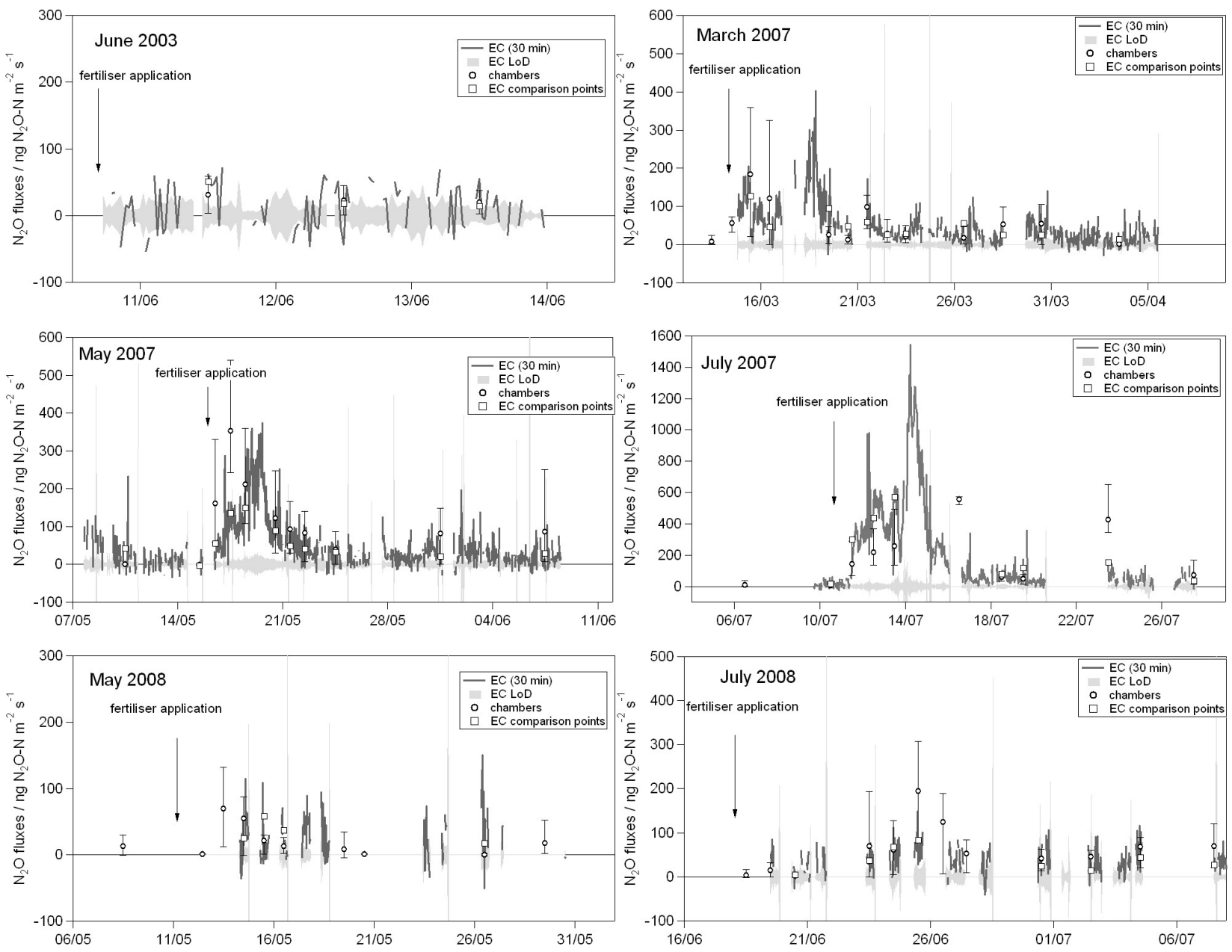

Fig. 2. $\mathrm{N}_{2} \mathrm{O}$ fluxes obtained with eddy covariance and static chambers for 6 comparison periods; eddy covariance data are 30 min values (grey line) or values averaged over the one hour period when chambers were closed (between 10:00-12:00, squares). Chamber measurement points represent the average of 14 (2003) or 4 (2007/2008) chambers measured over $1 \mathrm{~h}$ (white circles), with error bars representing the range of chamber measurements. Fertiliser applications are indicated with an arrow.

(including bad wind sector, and electronic noise beside the filtering criteria listed above) resulted in a final data capture for the EC fluxes of $69 \%$ in June 2003, $63 \%$ in March 2007, $65 \%$ in May 2007, $63 \%$ in June 2007, 24\% in May 2008 and $23 \%$ in July 2008.

\subsection{Additional measurements}

Soil temperature and volumetric soil moisture were continuously recorded at four depths $(3.5 / 7.5 / 15 / 30 \mathrm{~cm})$ on each field by temperature probes (temperature probe 107, Campbell Scientific, Loughborough, UK) and TDR probes (TDR 100, Campbell Scientific, Loughborough, UK), respectively. Rain was measured by a tipping bucket rain gauge in the middle of the measuring site. Extractable soil mineral $\mathrm{N}_{\left(\mathrm{NH}_{4}^{+}\right.}$ and $\mathrm{NO}_{3}^{-}$) was determined in samples collected at two depths $(0-5 \mathrm{~cm}$ and $5-15 \mathrm{~cm})$, collected weekly around fertiliser applications, and samples were frozen at $-16^{\circ} \mathrm{C}$ until analysis.
Soil mineral $\mathrm{N}$ content was measured from four bulked soil samples using continuous flow colorimetric analysis of $1 \mathrm{M}$ $\mathrm{KCl}$ extracts from field-moist soil using a soil:solution ratio of 1:5, following the method of Crooke and Simpson (1971) and Henriksen and Selmer-Olsen (1970).

\subsection{Statistical analysis and calculation of cumulative fluxes}

Eddy covariance fluxes were measured every half hour, while chamber fluxes were measured once a day over one hour periods, roughly between 10:00 and 12:00, although data were not collected every day; the data series from half hourly EC fluxes including limit of detection and chambers fluxes are shown in Fig. 2. Table 2 provides a summary of statistics for the fluxes measured by both methods. EC fluxes were averaged over the period of chamber closure: for these comparison points (plotted in Fig. 2 as squares), the selected 

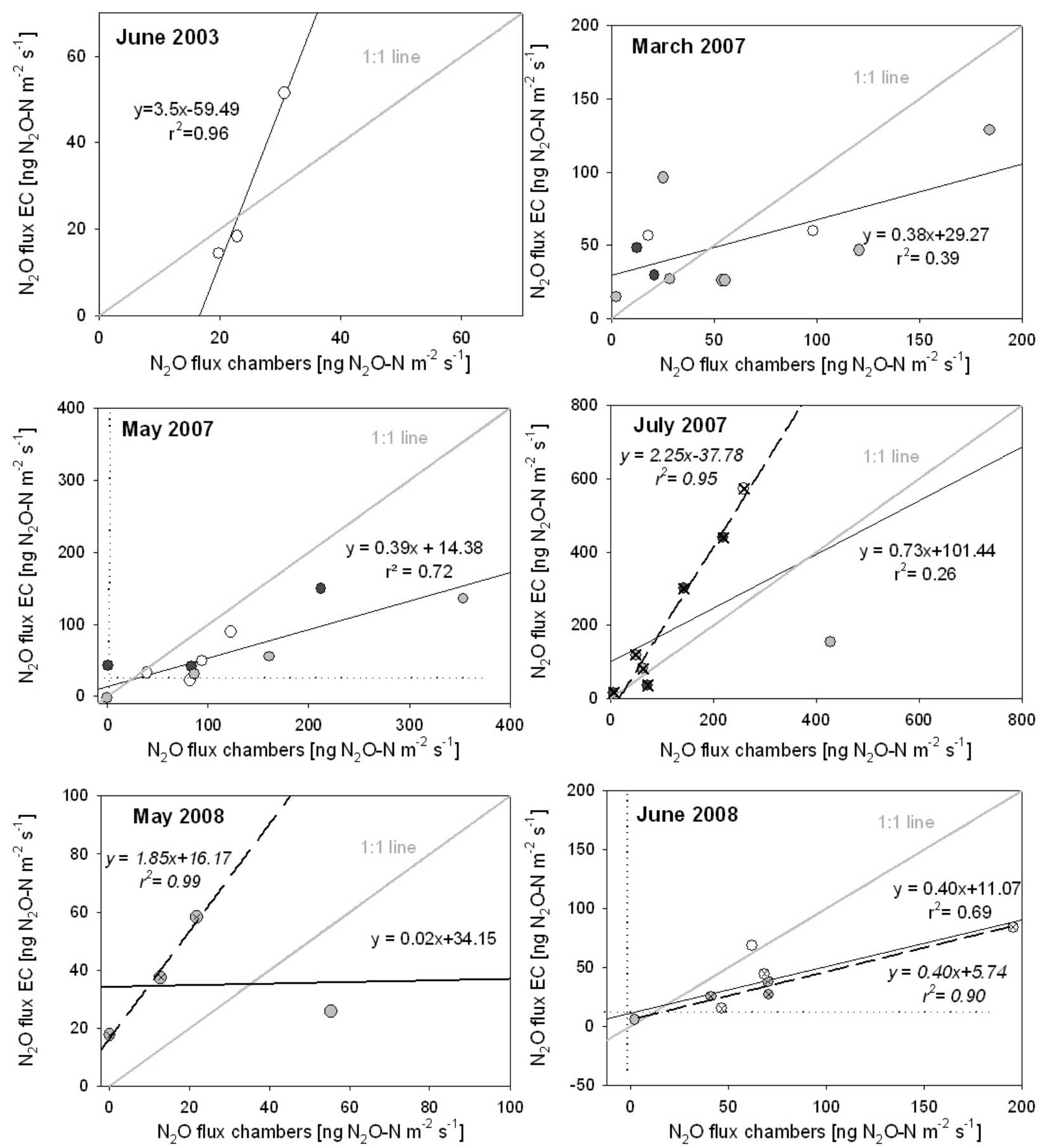

Fig. 3. Comparison of $\mathrm{N}_{2} \mathrm{O}$ fluxes measured at the same times (between 10:00 and 12:00) with eddy covariance (EC) and static chambers for each of the 6 comparison periods and data from all comparison periods. Chamber values represent an average of 14 (2003) or 4 (2007/2008) chambers. Circles represent all comparison points, while crosses represent the retained dataset where outliers were removed. Trend lines represent orthogonal regression (continuous line for all comparison points with non italic model equation, dashed line where outliers were removed with italic model equation). Different shades of circles indicate the contribution of the area in which the chambers were situated to the footprint of the EC measurement (open circles $=0-25 \%$, medium grey $=26-50 \%$, dark grey $=51-75 \%$ ). 
chambers were chosen by wind sector selection (amongst 14 chambers in the South field in 2003 and 4 chambers from either South or North field in 2007 and 2008). The probability of all four chambers being within the EC footprint was calculated by footprint analysis, using the approach by Neftel et al. (2008) for data in 2007 and 2008; the results of this analysis are shown in Fig. 3, where a colour scale on the circles indicates the probability of the chambers to be included in the EC footprint.

We then calculated cumulative $\mathrm{N}_{2} \mathrm{O}$ fluxes for both methods, using different averaging intervals (hourly, daily, and over the whole period) and assessing their impact on the estimate of the emission factors for inventories. Cumulative $\mathrm{N}_{2} \mathrm{O}$ fluxes were calculated over each comparison period using the chambers values as daily averages: all daily fluxes belonging to a comparison period were averaged and multiplied by the number of days (non gap-filled cumulative flux). The missing daily values were then inferred by linear interpolation, and integrated over each period (gap-filled cumulative flux).

The EC cumulative fluxes were calculated using different averaging intervals:

1. EC ${ }^{\mathrm{a}}$ : EC hourly comparison points (measured during chamber closure) were used as daily values, averaged and multiplied by the number of days in each comparison period.

2. $\mathrm{EC}^{\mathrm{b}}$ : EC half hourly fluxes were averaged daily, averaged again and multiplied by the number of days in each period.

3. $\mathrm{EC}^{\mathrm{c}}$ : half hourly EC fluxes were averaged over each comparison period.

Similarly to the chambers, the cumulative fluxes from the EC data were calculated from non gap-filled (as seen above) and gap-filled data: if half-hour fluxes were missing, the values were inferred by linear interpolation of previous and following data. For the daily fluxes $\mathrm{EC}^{\mathrm{b}}$ and $\mathrm{EC}^{\mathrm{a}}$, if no $30 \mathrm{~min}$ values were available for $24 \mathrm{~h}$, the missing daily value was calculated by linear interpolation of the previous and following daily value. All cumulative fluxes are listed in Table 3, for gap-filled and non-gap-filled data.

The cumulative fluxes from the chambers were then compared to the three different cumulative fluxes from EC, for each comparison period, using orthogonal regression (see Fig. 3) to avoid biasing the outcome towards one method to the disadvantage of the other.

\section{Results}

The length of the different comparisons ranged between 3 and 29 days and the rate of $\mathrm{N}$ applications varied between 48 and $69 \mathrm{~kg} \mathrm{Nha}^{-1}$ per period (see Table 1): a variety of environmental conditions was covered, reflected by the wide range of the measured $\mathrm{N}_{2} \mathrm{O}$ fluxes. Rainfall varied between 2 and $120 \mathrm{~mm}$ per period, corresponding to an average of 0.7 to $4.1 \mathrm{~mm}$ of rainfall per day. Soil water content (SWC) was lowest in June 2003 (35\%) and May 2008 (36\%), and highest in March 2007 (47\%), corresponding to water filled pore space values (WFPS) of $65 \%, 66 \%$ and $87 \%$, respectively. Average soil temperatures ranged from $5.6^{\circ} \mathrm{C}$ (March 2007) to $14.0^{\circ} \mathrm{C}$ (July 2007).

\subsection{Magnitude and variability of $\mathrm{N}_{2} \mathrm{O}$ fluxes}

Throughout the manuscript, positive values represent emission, and negative values deposition fluxes. An increase of $\mathrm{N}_{2} \mathrm{O}$ emission after the $\mathrm{N}$ application was observed after all fertilization events in 2007 and 2008 by both methods (see Fig. 2). Fluxes declined to background levels (here defined as average daily flux below $50 \mathrm{ng}_{2} \mathrm{O}-\mathrm{N} \mathrm{m}^{-2} \mathrm{~s}^{-1}$ ) after 2 to 6 days. No response in $\mathrm{N}_{2} \mathrm{O}$ emissions to fertilizer input was observed in June 2003 by either method. Highest fluxes were measured in July 2007, with maximum values of $1438 \mathrm{ng} \mathrm{N}_{2} \mathrm{O}-\mathrm{N} \mathrm{m}^{-2} \mathrm{~s}^{-1}$ measured by EC on the $14 \mathrm{July}$, and $651 \mathrm{ng} \mathrm{N}_{2} \mathrm{O}-\mathrm{N} \mathrm{m}^{-2} \mathrm{~s}^{-1}$ measured by the chambers on the 23 July. During this period the average soil temperature was $14.0^{\circ} \mathrm{C}$, the highest of all comparison periods, and the soil water content (SWC) was $45 \%$, corresponding to a WFPS of $83 \%$. In June 2003 and May 2008 fluxes were generally small with maximum values reaching $81.2 \mathrm{ng} \mathrm{N}_{2} \mathrm{O}-\mathrm{N}$ $\mathrm{m}^{-2} \mathrm{~s}^{-1}$ measured by EC and $91 \mathrm{ng} \mathrm{N} \mathrm{N}_{2} \mathrm{O}-\mathrm{N} \mathrm{m}^{-2} \mathrm{~s}^{-1}$ measured by chamber methods in 2003, while corresponding values in May 2008 were $150.9 \mathrm{ng} \mathrm{N}_{2} \mathrm{O}-\mathrm{N} \mathrm{m}^{-2} \mathrm{~s}^{-1}$ and $87.8 \mathrm{ng}$ $\mathrm{N}_{2} \mathrm{O}-\mathrm{N} \mathrm{m}^{-2} \mathrm{~s}^{-1}$. During both these periods soil conditions were dry (35\% and $36 \%$ SWC, respectively) with an average daily rainfall of 0.7 and $1.4 \mathrm{~mm}$ respectively, the lowest of all comparison periods.

Negative fluxes were observed in all events by EC while by chamber method negative fluxes were not seen in June 2003 and July 2007. $\mathrm{N}_{2} \mathrm{O}$ uptake was observed in $5 \%$ of all 30 min EC data (ranging from 2-25\%). Largest negative values were measured in 2003 with up to $-67 \mathrm{ng} \mathrm{N}_{2} \mathrm{O}-\mathrm{N}$ $\mathrm{m}^{-2} \mathrm{~s}^{-1}$ by EC, whereas with the chamber method largest negative fluxes of only $-3.1 \mathrm{ng} \mathrm{N}_{2} \mathrm{O}-\mathrm{N} \mathrm{m}^{-2} \mathrm{~s}^{-1}$ were measured in March 2007. For EC data, $5 \%$ of all measured fluxes were negative above the calculated detection limit, while for chamber measurements negative fluxes were always below the detection limit $(4.4 \%$ of all chamber measurements resulted negative).

The variation between maximum and minimum fluxes measured by EC on days immediately after $\mathrm{N}$ application, when fluxes were above background levels, was on average $378 \mathrm{ng} \mathrm{N}_{2} \mathrm{O} \mathrm{m}^{-2} \mathrm{~s}^{-1}$, compared to an average variation of $81 \mathrm{ng} \mathrm{N}_{2} \mathrm{O} \mathrm{m}^{-2} \mathrm{~s}^{-1}$ on days where fluxes were at background levels. However, no diurnal patterns with minimum fluxes at night and maximum fluxes at midday could be seen at any day in any comparison period and no correlation could be found between $\mathrm{N}_{2} \mathrm{O}$ fluxes and soil temperature or soil 
Table 2. Statistics of $\mathrm{N}_{2} \mathrm{O}$ fluxes from chambers and eddy covariance (EC) measurements for all 6 comparison periods. Numbers in brackets represent the number of chambers included in the comparison. EC points are eddy covariance hourly averages during chamber sampling (between 10:00 and 12:00); EC all are half hourly eddy covariance fluxes during the comparison period. The Coefficient of Variation is averaged over all measurements (30 min or daily values).

\begin{tabular}{|c|c|c|c|c|c|c|c|c|c|}
\hline \multirow[t]{2}{*}{ Comparison period } & \multirow[t]{2}{*}{ Method } & \multirow{2}{*}{$\begin{array}{r}N \\
\text { no. of values }\end{array}$} & \multicolumn{6}{|c|}{$\mathrm{N}_{2} \mathrm{O}$ flux [ng $\left.\mathrm{N}_{2} \mathrm{O}-\mathrm{N} \mathrm{m}^{-2} \mathrm{~s}^{-1}\right]$} & \multirow[b]{2}{*}{$\mathrm{CV} \%$} \\
\hline & & & $\min$ & $25 \%$ & mean & median & $75 \%$ & $\max$ & \\
\hline \multirow{3}{*}{ 11.6.-13.6. 2003} & chambers (15) & 45 & 0.4 & 6.9 & 24.5 & 17.9 & 35.4 & 91.0 & 108.3 \\
\hline & EC points & 3 & 14.4 & 16.4 & 28.1 & 18.4 & 34.9 & 51.4 & 72.4 \\
\hline & EC all & 100 & -67.4 & -17.0 & 12.2 & 18.4 & 40.6 & 81.2 & 283.0 \\
\hline \multirow[t]{3}{*}{ 15.3.-3.4. 2007} & chambers (4) & 44 & -3.1 & 7.7 & 56.4 & 27.3 & 70.1 & 359.1 & 139.3 \\
\hline & EC points & 11 & 14.6 & 26.6 & 50.8 & 46.7 & 58.0 & 128.7 & 67.7 \\
\hline & EC all & 574 & -30.5 & 13.1 & 47.3 & 31.7 & 60.9 & 403.5 & 115.4 \\
\hline \multirow[t]{3}{*}{ 10.5.-7.6. 2007} & chambers (4) & 44 & -2.6 & 7.5 & 112.3 & 84.5 & 153.7 & 540.5 & 109.4 \\
\hline & EC points & 11 & -2.4 & 31.4 & 58.6 & 42.1 & 72.4 & 149.5 & 80.7 \\
\hline & EC all & 861 & -34.1 & 10.6 & 44.6 & 25.9 & 59.3 & 314.4 & 129.8 \\
\hline \multirow[t]{3}{*}{ 10.7.-27.7. 2007} & chambers (4) & 32 & 3.1 & 45.1 & 154.9 & 97.0 & 207.9 & 651.2 & 102.6 \\
\hline & EC points & 8 & 16.2 & 70.3 & 215.1 & 137.0 & 335.5 & 572.6 & 94.2 \\
\hline & EC all & 554 & -57.0 & 27.7 & 260.2 & 64.1 & 290.7 & 1438.1 & 74.9 \\
\hline \multirow[t]{3}{*}{ 14.5.-26.5. 2008} & chambers (4) & 16 & -1.7 & 1.5 & 22.6 & 12.0 & 30.3 & 87.8 & 125.2 \\
\hline & EC points & 4 & 17.7 & 23.7 & 34.8 & 31.6 & 42.6 & 58.3 & 50.7 \\
\hline & EC all & 111 & -51.2 & 3.7 & 29.3 & 22.2 & 55.5 & 150.9 & 125.2 \\
\hline \multirow[t]{3}{*}{ 20.6.-7.7. 2008} & chambers (4) & 32 & -0.18 & 14.2 & 69.7 & 56.1 & 90.0 & 308.5 & 104.0 \\
\hline & EC points & 8 & 5.8 & 22.8 & 38.7 & 32.6 & 50.7 & 84.4 & 68.8 \\
\hline & EC all & 219 & -42.6 & 17.6 & 42.8 & 39.1 & 59.4 & 371.3 & 96.9 \\
\hline
\end{tabular}

moisture on any day. The difference between average night (20:00-08:00) and day (08:00-20:00) time emissions was never significant, indicating that other drivers (time after fertilizer application, or rain events) played a more important role than parameters that are subject to a diurnal cycle (temperature, turbulence, heat fluxes).

Over all comparison periods, the largest $\mathrm{N}_{2} \mathrm{O}$ fluxes amounted to $1438 \mathrm{ng} \mathrm{N}_{2} \mathrm{O}-\mathrm{N} \mathrm{m}^{-2} \mathrm{~s}^{-1}$ in July 2007 (see Table 2). Despite the observed negative fluxes, median and average fluxes over each period were always positive. Median $\mathrm{N}_{2} \mathrm{O}$ fluxes ranged from 12.0 to $97 \mathrm{ng} \mathrm{N}_{2} \mathrm{O}-\mathrm{N} \mathrm{m}^{-2} \mathrm{~s}^{-1}$ for chamber methods, from 18.4 to $137 \mathrm{ng} \mathrm{N}_{2} \mathrm{O}-\mathrm{N} \mathrm{m}^{-2} \mathrm{~s}^{-1}$ for the corresponding EC comparison points, and from 18.4 to $64.1 \mathrm{ng} \mathrm{N}_{2} \mathrm{O}-\mathrm{N} \mathrm{m}^{-2} \mathrm{~s}^{-1}$ for all EC data. Mean fluxes were on average 2.1 times larger than median fluxes, indicating that fluxes were not normally distributed.

The variability of $\mathrm{N}_{2} \mathrm{O}$ fluxes was expressed as coefficient of variation (defined here as the ratio between the standard deviation and the mean, expressed in percentage: CV $\%=(\sigma / \mu) \times 100)$ calculated for both measuring techniques. When looking at fluxes during chamber closure, the CV for chamber measurements was always higher than for EC (the highest was measured in March 2007 at 139.3\%). The same can be said for the overall half-hourly $\mathrm{N}_{2} \mathrm{O}$ EC fluxes, exception made for the periods of June 2003 and May 2008, where the variation of the overall half-hourly $\mathrm{N}_{2} \mathrm{O}$ EC fluxes was higher compared to the chambers, with the highest CV observed in June 2003 at $283 \%$.

\subsection{Comparison of fluxes during chamber closure time}

The range of $\mathrm{N}_{2} \mathrm{O}$ fluxes measured at the same time by different chambers varied widely. It was largest on the 15 March 2007, at $338 \mathrm{ng} \mathrm{N}_{2} \mathrm{O}-\mathrm{N} \mathrm{m}^{-2} \mathrm{~s}^{-1}$, immediately after fertilizer application and smallest on the 10 May 2007, at $2 \mathrm{ng} \mathrm{N} \mathrm{N}_{2} \mathrm{O}-\mathrm{N} \mathrm{m}^{-2} \mathrm{~s}^{-1}$, five days before fertilizer application. EC fluxes during chamber closure were within the range of the chamber measurements in $69 \%$ of the cases over the 6 comparison periods (ranging from $25 \%$ in May 2008 to $100 \%$ in June 2003).

Scatter-plots showing orthogonal regression between chamber and EC measurements made during the same sampling hours are shown in Fig. 3 for all periods. The number of points per period varied from 3 (June 2003) to 11 (May-June 2007, July 2007). In 6 out of 6 comparison periods there was a positive correlation between values from both methods. In June 2003 and May 2008 EC fluxes were higher compared to chamber measurements. For all other comparison periods it was the opposite, with EC values being $38 \%\left(r^{2}=0.39\right), 39 \%\left(r^{2}=0.72\right), 73 \%\left(r^{2}=0.26\right)$ and $40 \%\left(r^{2}=0.69\right)$ of the chambers for March, May and June 2007 and July 2008, respectively. The elimination of one outlier in July 2007 changed the story radically, with EC values being $225 \%\left(r^{2}=0.95\right)$ of chamber measurements. In May 2008 the regression was very close to zero, but the removal of one outlier improved the correlation $\left(r^{2}\right.$ from 0.2 to 0.99 ) and clearly set the EC values above the chambers. 
Table 3. Cumulative $\mathrm{N}_{2} \mathrm{O}$ fluxes from chambers and eddy covariance for all 6 periods. Fluxes were calculated using both non gap-filled and gap-filled data. Values in brackets represent standard deviations amongst 14 (2003) or 4 (2007/2008) chambers.

\begin{tabular}{|c|c|c|c|}
\hline \multirow[t]{2}{*}{ Comparison period } & \multirow[t]{2}{*}{ Method } & \multicolumn{2}{|c|}{ Cumulative $\mathrm{N}_{2} \mathrm{O}$ flux $\left[\mathrm{kg} \mathrm{N} \mathrm{ha}^{-1}\right.$ comparison period $\left.{ }^{-1}\right]$} \\
\hline & & Non-gap-filled data & gap-filled data \\
\hline \multirow[t]{4}{*}{ 11.6.-13.6. 2003} & chambers & $0.06( \pm 0.05)$ & $0.06( \pm 0.05)$ \\
\hline & $\mathrm{EC}^{\mathrm{a}}$ & 0.07 & 0.07 \\
\hline & $\mathrm{EC}^{\mathrm{b}}$ & 0.032 & 0.032 \\
\hline & $\mathrm{EC}^{\mathrm{c}}$ & 0.032 & 0.038 \\
\hline \multirow[t]{4}{*}{ 15.3.-3.4. 2007} & chambers & $0.98( \pm 0.45)$ & $0.85( \pm 0.40)$ \\
\hline & $\mathrm{EC}^{\mathrm{a}}$ & 0.834 & 0.791 \\
\hline & $\mathrm{EC}^{\mathrm{b}}$ & 1.003 & 1.003 \\
\hline & $\mathrm{EC}^{\mathrm{c}}$ & 0.935 & 0.872 \\
\hline \multirow[t]{4}{*}{ 10.5.-7.6. 2007} & chambers & $2.05( \pm 1.22)$ & $2.02( \pm 1.03)$ \\
\hline & $\mathrm{EC}^{\mathrm{a}}$ & 1.418 & 1.037 \\
\hline & $\mathrm{EC}^{\mathrm{b}}$ & 0.89 & 0.92 \\
\hline & $\mathrm{EC}^{\mathrm{c}}$ & 1.05 & 0.92 \\
\hline \multirow{4}{*}{ 10.7.-27.7. 2007} & chambers & $2.41( \pm 0.7)$ & $2.89( \pm 0.74)$ \\
\hline & $\mathrm{EC}^{\mathrm{a}}$ & 2.94 & 2.69 \\
\hline & $\mathrm{EC}^{\mathrm{b}}$ & 2.04 & 2.18 \\
\hline & $\mathrm{EC}^{\mathrm{c}}$ & 2.60 & 2.18 \\
\hline \multirow[t]{4}{*}{ 14.5.-26.5. 2008} & chambers & $0.25( \pm 0.17)$ & $0.13( \pm 0.09)$ \\
\hline & $\mathrm{EC}^{\mathrm{a}}$ & 0.58 & 0.68 \\
\hline & $\mathrm{EC}^{\mathrm{b}}$ & 0.43 & 0.43 \\
\hline & $\mathrm{EC}^{\mathrm{c}}$ & 0.45 & 0.47 \\
\hline \multirow[t]{4}{*}{ 20.6.-7.7. 2008} & chambers & $1.14( \pm 0.56)$ & $1.26( \pm 0.60)$ \\
\hline & $\mathrm{EC}^{\mathrm{a}}$ & 0.90 & 0.86 \\
\hline & $\mathrm{EC}^{\mathrm{b}}$ & 0.68 & 0.95 \\
\hline & $\mathrm{EC}^{\mathrm{c}}$ & 0.69 & 0.95 \\
\hline
\end{tabular}

${ }^{\mathrm{a}}$ Using only eddy covariance comparison points (over chamber closure times, between 10:00 h and 12:00 h), ${ }^{\mathrm{b}}$ using daily averages calculated from half hourly fluxes by eddy covariance, ${ }^{\mathrm{c}}$ using all eddy covariance 30 min data.

The elimination of two outliers in June 2008 increased $r^{2}$ from 0.69 to 0.90 , but did not change the story, EC fluxes being still $40 \%$ of chambers ones. Overall, EC fluxes were $70 \%$ of the fluxes from chambers.

\subsection{Cumulative fluxes}

Cumulative fluxes were calculated for each comparison period for both measuring techniques (see Table 3 for a summary). In the literature, cumulative fluxes are often calculated from non-gap-filled data, by averaging all data and multiplying the average by the number of time steps. They can also be calculated by summing up gap-filled data (by linear interpolation) or by a combination of both integration methods (e.g. if fluxes are divided into "triggered emission events" and "background fluxes", see Flechard et al., 2005). To investigate the influence of the integration method on cumulative flux values and therefore on emission factors, we calculated cumulative $\mathrm{N}_{2} \mathrm{O}$ fluxes by both frequently used integration methods. For chamber measurements, using non gap-filled data led to larger cumulative fluxes in 4 out of the 6 comparison periods; the differences induced by the in- tegration method ranged from 0 (June 2003) to a factor 2 (May 2008). For EC measurements differences induced by the integration method ranged from $0 \%$ (June 2003, EC ) to $50 \%$ (June 2003, $\mathrm{EC}^{\mathrm{c}}$ ). Over all comparison periods fluxes from non-gap-filled data represented $83 \%$ of fluxes from gap-filled data for chamber measurements $\left(r^{2}=0.97\right)$, $111 \%$ for $\mathrm{EC}^{\mathrm{a}}\left(r^{2}=0.97\right), 92 \%$ for $\mathrm{EC}^{\mathrm{b}}\left(r^{2}=0.97\right)$ and $120 \%$ for $\mathrm{EC}^{\mathrm{c}}\left(r^{2}=0.96\right)$.

Cumulative fluxes calculated from $\mathrm{EC}^{\mathrm{a}}$ were within one standard deviation of the chamber measurements for all comparison periods with the exception of May 2008. Cumulative $\mathrm{EC}^{\mathrm{a}}$ fluxes represented $72 \%$ of chamber fluxes $\left(r^{2}=\right.$ 0.81 ) when using gap-filled data. Excluding June 2003 and May 2008, all cumulative fluxes from chambers were larger than $\mathrm{EC}^{\mathrm{a}}$ fluxes (up to 1.9 times), when using gap-filled data.

Cumulative fluxes calculated from both gap-filled and non-gap-filled $\mathrm{EC}^{\mathrm{a}}$ were mostly larger than $\mathrm{EC}^{\mathrm{b}}$ except for March 2007 and June 2008 (i.e. remove gap-filled), when using gap-filled data, $\mathrm{EC}^{\mathrm{a}}$ were $144 \%$ of $\mathrm{EC}^{\mathrm{b}}\left(r^{2}=0.97\right)$. Cumulative fluxes calculated from all data $\left(\mathrm{EC}^{\mathrm{c}}\right)$ were the lowest compared to any other EC fluxes or chambers, both 
in case of gap-filled and non-gap-filled data: they were $79 \%$ of $\mathrm{EC}^{\mathrm{a}}, 98 \%$ of $\mathrm{EC}^{\mathrm{b}}$, and $59 \%$ of chambers. The different averaging protocols for EC data have been plotted against the cumulative chamber fluxes in Fig. 4. The highest cumulative fluxes were the $\mathrm{EC}^{\mathrm{a}}$ : they show the closest agreement with the chambers fluxes as it is more likely to expect (with a slope of 0.71), considering they represent the same hours of sampling. $\mathrm{EC}^{\mathrm{c}}$ and $\mathrm{EC}^{\mathrm{b}}$ show a very similar behavior, with lower slopes (0.6). Overall, the EC fluxes provide cumulative estimates that are lower than the chambers at the high end of the emission range, but higher at the lower end.

\section{Discussion}

There are uncertainties in both chamber and EC approaches. As mentioned above, micro-climate and the concentration gradient between the soil and the atmosphere may be altered within a chamber and their small footprint makes them very sensitive to local soil conditions. It has also been demonstrated that chambers present a problem of underestimation of the fluxes if operated without a fan (see Pumpanen et al., 2004; Christiansen et al., 2011). An important additional uncertainty for chamber measurements in grazed and fertilized grassland systems is their effect on grazing behaviour in and around the chamber, and the statistical variability in the fertilizer application across the field. Eddy-covariance measurements are as well subject to some artefacts: flux losses can arise e.g. from limited sensor response times, damping of fluctuations in the sampling line and spatial separation of wind and concentration measurement (e.g. Moore, 1986; Aubinet et al., 2000). It has more recently been realized that the determination of the time-lag between the measurements of turbulence and $\mathrm{N}_{2} \mathrm{O}$ concentration as the lag with the largest cross-correlation (and therefore flux) can overestimate the flux (both negative and positive fluxes) if a noisy sensor is used (e.g. Taipale et al., 2010). In addition, parallel EC flux measurements with duplicate towers over the same site typically show average differences of $20 \%$ between $30 \mathrm{~min}$ values, due to statistical variations in turbulence, even for the sensible heat flux, which is derived by the anemometer itself (no time lag, sensor separation or damping). By contrast, long-term averages of duplicated measurements are very close because the statistical variability averages out (e.g. Dämmgen et al., 2005; Nemitz et al., 2009).

These uncertainties are of course very relevant during the data analysis process, and are in this work addressed as much as possible.

However, it is necessary to highlight the difference in magnitude of uncertainties linked to the two approaches, static chambers and eddy covariance. Chamber measurements will always be subject to a huge temporal and spatial variability, which makes it a difficult task to assess an integrated flux with an uncertainty of $50 \%$ or $75 \%$ (with no information on over- or under-estimation). With EC, taking into account all issues discussed above for the time-integrated flux, the uncertainty would be around $20 \%$ (and also more likely to be an underestimate, due to losses).

\subsection{Influence of management, soil water and temperature on $\mathrm{N}_{2} \mathrm{O}$ fluxes}

The magnitude of $\mathrm{N}_{2} \mathrm{O}$ fluxes measured by chamber and EC methods in our study are comparable with those measured at other European managed grassland sites (e.g. Flechard et al., 2007), although they are at the top end of observed fluxes. This is likely to be due to the influence of grazing and the specific soil and climatic conditions at our experimental site. As most Scottish soils, the soil at Easter Bush is high in organic matter $\left(12.1 \mathrm{~kg} \mathrm{~m}^{-2}\right)$. The high soil organic matter, together with the input of labile $\mathrm{C}$ from added dung and urine by grazing animals, is likely to have increased denitrification rates by providing substrates for denitrifiers and by stimulating microbial activity (Granli and Bockmann, 1994; Lessard et al., 1996). Furthermore, grazing leads to compaction of the soil, which has been shown to enhance $\mathrm{N}_{2} \mathrm{O}$ production by decreasing oxygen diffusion (Simek et al., 2006). Although the average total annual rainfall at our site is comparable with that across much of central Europe, the rainfall in Scotland is distributed evenly over the year, providing moist condition that favor denitrification throughout most of the year.

In 4 out of 6 comparison periods we have observed the typical short-lived increase of $\mathrm{N}_{2} \mathrm{O}$ emissions after mineral $\mathrm{N}$ applications as reported in many studies (e.g. Clayton et al., 1997; Leahy et al., 2004; Jones et al., 2007). Largest fluxes were observed in May and July 2007 and June 2008, when the average WFPS ranged between 72 and $84 \%$ (Table 1). An optimum level for maximum $\mathrm{N}_{2} \mathrm{O}$ emission was suggested to be around $65 \%$ (Davidson, 1991), $75 \%$, (Flechard et al., 2007), 80-85\% (Dobbie et al., 1999; Skiba and Smith, 2000 ) or $85 \%$ (Ruser et al., 1998). Although the WFPS was highest in March 2007 (85\%), fluxes were relatively small during this period, probably due to the low average temperature of $5.6^{\circ} \mathrm{C}$. This temperature is close to the critical temperature of $5^{\circ} \mathrm{C}$, below which nitrification and denitrification rates have been shown to be negligible in temperate grasslands (Vinther, 1990). In June 2003 and May 2008, where WFPS was on average lowest (66\% and 68\%) compared with other comparison periods (Table 1), $\mathrm{N}_{2} \mathrm{O}$ fluxes were always close to background level. It is possible that these two periods were too dry, and mineral $\mathrm{N}$ from fertilizer input was taken up by plants directly instead of being nitrified and subsequently denitrified.

No significant relationships were observed between $\mathrm{N}_{2} \mathrm{O}$ fluxes, soil water content and soil temperature for either flux measurement methods when investigating all data points per comparison period. This is likely to be due to the competing influences of soil water content, soil temperature and the changing availability of $\mathrm{N}$ on microbial processes. Soil moisture as well as soil temperatures were relatively stable 


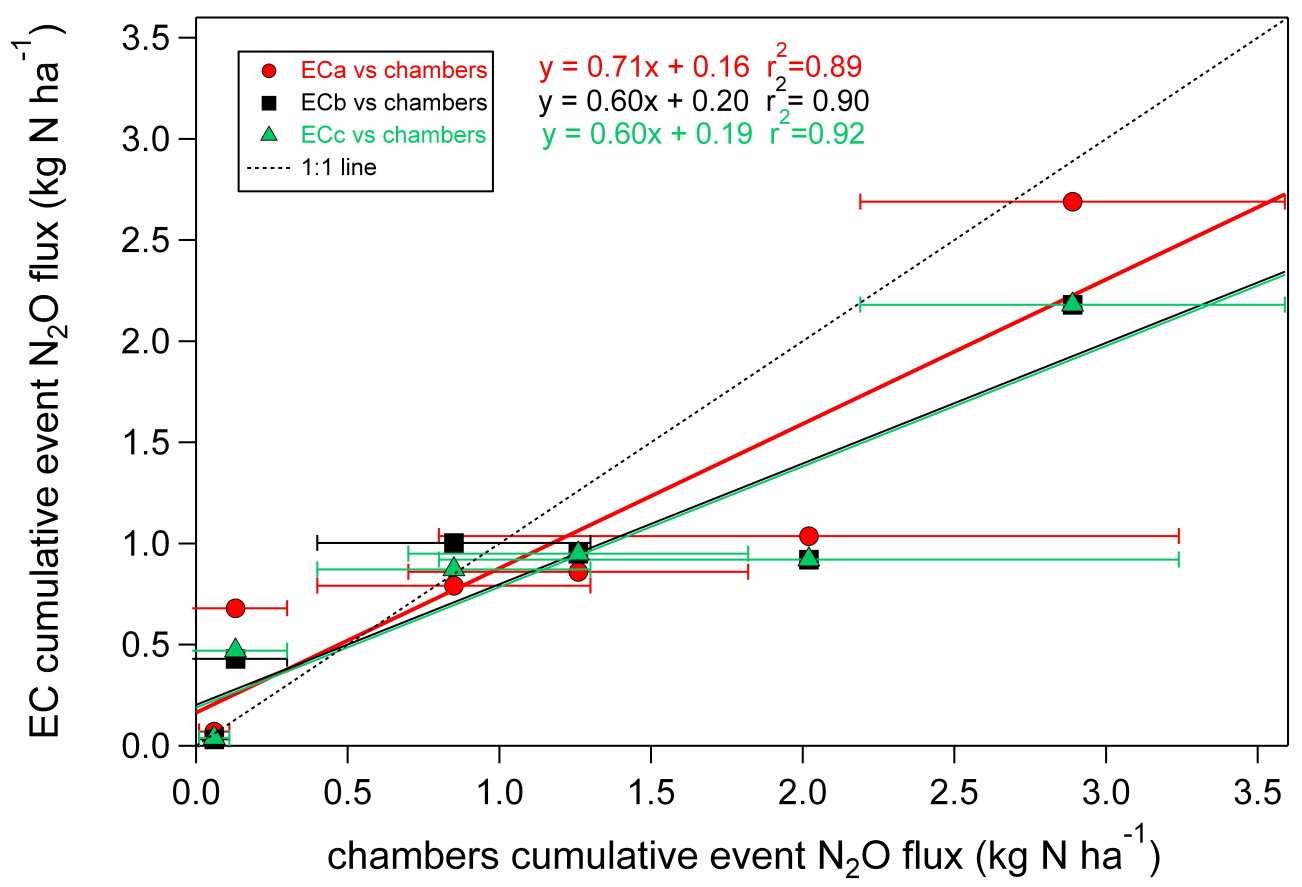

Fig. 4. Comparison of cumulative fluxes from gap-filled data from static chambers and EC, using either comparison points $\left(\mathrm{EC}^{\mathrm{a}}\right)$, daily averages $\left(\mathrm{EC}^{\mathrm{b}}\right)$ or 30 min values $\left(\mathrm{EC}^{\mathrm{c}}\right)$.

throughout each comparison period $(\mathrm{CVs}$ ranged between 1.7 and $9.7 \%$, for soil moisture and 4.6 to $22.3 \%$ for soil temperature). In contrast, mineral $\mathrm{N}$ in the soil was generally larger after $\mathrm{N}$ application and smaller towards the end of each comparison period, while $\mathrm{N}$ from urine and dung patches from grazing animals was likely to have varied over space and time. A positive correlation between $\mathrm{N}_{2} \mathrm{O}$ fluxes measured by chambers with $\mathrm{NO}_{3}^{-}$in the $0-5 \mathrm{c} \mathrm{m}$ soil layer is seen when considering data from all comparison $\left(r^{2}=0.80\right)$.

\subsection{Negative $\mathrm{N}_{2} \mathrm{O}$ fluxes measured by $\mathrm{EC}$ and chamber method}

Uptake of $\mathrm{N}_{2} \mathrm{O}$ in soils has been reported for grasslands in several studies (e.g. Ryden, 1981; Flechard et al., 2005; Neftel et al., 2007, 2010). It is generally assumed that $\mathrm{N}_{2} \mathrm{O}$ uptake is a microbial process in which denitrifiers use $\mathrm{N}_{2} \mathrm{O}$ as an electron acceptor for respiration, when oxygen is limited in wet, poorly aerated soils (Bremner, 1997). However, $\mathrm{N}_{2} \mathrm{O}$ uptake has also been measured under dry conditions, as oxygen limited sites can develop in well aerated soils inside anaerobic microsites (Hojberg at al., 1994). Denitrifiers are able to use $\mathrm{NO}_{3}^{-}, \mathrm{NO}_{2}^{-}$, and $\mathrm{NO}$ as electron acceptors under anaerobic conditions and complete denitrification (reduction of $\mathrm{N}_{2} \mathrm{O}$ to $\mathrm{N}_{2}$ ) is thought to occur predominantly when $\mathrm{N}_{2} \mathrm{O}$ is the only remaining electron acceptor. High $\mathrm{NO}_{3}^{-}$concentrations are therefore expected to suppress $\mathrm{N}_{2} \mathrm{O}$ uptake. In fact, many authors have reported links between low $\mathrm{NO}_{3}^{-}$concentrations and net $\mathrm{N}_{2} \mathrm{O}$ uptake on grasslands (e.g. Ryden, 1981; Clayton et al., 1997; Flechard et al., 2005). The flux data presented in this study were all measured immediately after $\mathrm{N}$ application and high $\mathrm{N}_{2} \mathrm{O}$ uptake was therefore not anticipated. Indeed chamber measurements only showed occasional $\mathrm{N}_{2} \mathrm{O}$ uptake at the end of comparison periods when $\mathrm{N}_{2} \mathrm{O}$ fluxes were at background levels and $\mathrm{NO}_{3}^{-}$concentrations are assumed to be low. Also Clayton et al. (1997) reported occasional $\mathrm{N}_{2} \mathrm{O}$ uptake by a fertilized grassland in intervals between fertilizer applications. In July 2007 at Easter Bush the same pattern of $\mathrm{N}_{2} \mathrm{O}$ uptake was observed by both chamber and EC measurements. However, chamber measured fluxes were never above detection limit. For all other comparison periods, especially in 2003 and 2008, we measured negative fluxes by EC even shortly after $\mathrm{N}$ application. The magnitude of the negative fluxes measured in our study was at times larger than maximum negative values reported in the literature for grasslands (Chapuis-Lardy et al., 2006). For the EC data, the quality control criteria (see Methods section) removed a substantial amount of negative fluxes; although we are critical towards the highly negative fluxes based on the current knowledge of biological soil processes, we could not find a reason to reject those negative flux values without biasing the dataset. It has to be pointed out that until novel chemical analysers will allow less noise in the concentration measurements, the detection of small fluxes is a great challenge. The flux detection limits do not allow the resolution of uptake processes as they are described in controlled experiments; however, when averaging over long terms to get $\mathrm{N}_{2} \mathrm{O}$ emissions, that noise tends to be cancelled. 


\subsection{Spatial and temporal variability}

In order to compare the temporal and spatial variability of $\mathrm{N}_{2} \mathrm{O}$ fluxes measured by each method, coefficients of variation (CVs) were calculated over each comparison period (Table 2). CVs for chamber and EC measurements represent a combination of spatial and temporal variability. The observation that $\mathrm{CV}$ s of chamber measurements were higher than those from EC comparison points reflects the small scale spatial variability detected by the chambers. The high spatial variability of $\mathrm{N}_{2} \mathrm{O}$ fluxes at Easter Bush is highlighted by the high coefficients of variation of up to $139 \%$ and by the range of more than $300 \mathrm{ng} \mathrm{N}_{2} \mathrm{O}-\mathrm{N} \mathrm{m}^{-2} \mathrm{~s}^{-1}$ measured by 4 chambers within the same hour. Hotspots of high $\mathrm{N}_{2} \mathrm{O}$ emissions are driven by increased $\mathrm{N}$ input through animal urine and dung, and have been measured in fertilized and especially in grazed grasslands (Velthof et al., 1996; Skiba et al., 1998; Flechard et al., 2007). The spatial variability is due to fluctuations in mineral $\mathrm{N}$ content, oxygen levels and microbial communities within the soil. The varying $\mathrm{N}$ level is caused by a combination of fertilizer $\mathrm{N}$ application, the distribution of urine and dung patches, $\mathrm{N}$ uptake by the grass roots and microbial biomass and $\mathrm{N}$ losses by leaching, denitrification and volatilization (e.g. Velthof, 1995), while the oxygen level depends on the level of soil respiration, soil density and water content, all of which affect the formation of anaerobic zones (Ruser et al., 2006).

The variation in $\mathrm{N}_{2} \mathrm{O}$ fluxes by EC measured every $30 \mathrm{~min}$ was comparable to the chamber measurements. The variability that the datasets reflect are both spatial and temporal, but there are several factors favouring one or the other technique. Chamber measurements were only conducted once per day and therefore cannot represent short time scale events, such as large emission peaks, which are captured by EC.

The higher $\mathrm{CV}$ for $\mathrm{EC}^{\mathrm{c}}$ compared to $\mathrm{EC}^{\mathrm{a}}$ reflects the additional diurnal variability of $\mathrm{N}_{2} \mathrm{O}$ fluxes. However, when looking at the diurnal variation in detail we never observed a clear cycle with a maximum during the day and minimum during the night; neither did we find a correlation of $\mathrm{N}_{2} \mathrm{O}$ fluxes with soil temperature. This is in contrast to other studies (e.g. Du et al., 2006) and even to measurements taken on the same field in 2002, where clear diurnal cycles were measured with the same EC setup (Di Marco et al., 2004). This might be due to the lack of a pronounced soil temperature variation specific to the presented comparison periods.

\subsection{Comparison of chamber and EC flux measurements during chamber closure}

In our study nearly $70 \%$ of $\mathrm{N}_{2} \mathrm{O}$ fluxes measured by EC at the time of chamber closure were within the range of chamber measurements over all comparison periods. This is comparable with previous studies where Laville et al. (1997, 1999) and Christensen et al. (1996) found a reasonable agreement between $\mathrm{N}_{2} \mathrm{O}$ fluxes measured by EC and chamber methods. Laville et al. (1997 and 1999) compared fluxes over a period of 10 days, using 16 (1997) or 30 (1999) chambers for the comparison and fluxes were measured from bare fertilised soil and irrigated fertilised maize, respectively, while Christensen et al. (1996) compared fluxes over a period of 9 days using 32 chambers from unfertilised arable cropland. In $59 \%$ of all measurements in our study, chamber fluxes were higher than EC comparison points. EC fluxes ranged from $38 \%$ (March 2007) to 225\% (July 2007, after removal of outlier) of chamber measurements; considering all points of comparison, EC fluxes were $70 \%$ of chamber fluxes. In comparative experiments published by Smith et al. (1994) and Pilhatie et al. (2005) $\mathrm{N}_{2} \mathrm{O}$ flux values measured with EC were consistently lower than those from chamber methods. Smith et al. (1994 and 1998) measured fluxes over a period of 2 days from agricultural, fertilised grassland using 24 chambers while Pihlatie et al. (2005) presented a comparison period of 6 days from a beech forest using 35 chambers. As we measured fluxes over several periods of 3 to 29 days over several years, our study represents the longest intercomparison to date, spanning a large range of conditions. There are several reasons for the inconsistency observed on the same experimental field during different comparison periods in our study. It needs to be considered that the area which influences the EC measurement (flux footprint) might not always include the position of all the chambers, but only some of them. In Fig. 3 the different shades of symbols indicate the contribution of the area in which the chambers were situated to the footprint of the EC measurement according to this model (open circles $=0-25 \%$, medium grey $=26-50 \%$, dark grey $=51-75 \%$ ). This footprint analysis showed that the four chosen chambers (for 2007/2008) were in an area with a contribution to the measured flux ranging from 3.7 to $61.2 \%$. The disagreement of chamber and EC measurements might partly be explained by the potential for large-scale variability across the field, coupled with the fact that the area covered by the four chambers used for the comparison did not always dominate the EC flux measurement; thus, chambers and EC measurements were dominated by different parts of the field. Furthermore, even when the chambers are within the fetch of the EC method, the different techniques integrate fluxes over different spatial scales (e.g. Smith et al., 1994). The different averaging areas challenge a strict comparison of fluxes. As discussed above, it has been shown that $\mathrm{N}_{2} \mathrm{O}$ fluxes from soils have a high spatial variability, especially for grazed grasslands. High fluxes measured by chambers most likely represent hotspots, which in the EC approach are integrated alongside low emission areas.

\subsection{Cumulative fluxes}

Estimates of annual $\mathrm{N}_{2} \mathrm{O}$ fluxes are mainly based on measurements from manual chambers taken during daytime which are used as mean daily flux estimates to calculate cumulative fluxes (e.g. Clayton et al., 1997; Jones et al., 2007). However, cumulative annual fluxes calculated from a single 
measurement during the day could be biased by missing peak emission periods as well as ignoring possible diurnal pattern. Diurnal patterns of $\mathrm{N}_{2} \mathrm{O}$ fluxes after fertiliser applications usually have shown peak fluxes around midday in several studies (e.g. Di Marco et al., 2004; Flechard et al., 2005; Du et al., 2006). In order to examine if the magnitude of cumulative fluxes is biased due to one single sampling at midday, we compared cumulative fluxes calculated from $\mathrm{EC}$ daily means $\left(\mathrm{EC}^{\mathrm{b}}\right)$ with cumulative fluxes calculated from EC comparison points $\left(\mathrm{EC}^{\mathrm{a}}\right)$, which were taken simultaneously as chamber measurements, usually between 10:00 and 12:00 am. Over all comparison periods, cumulative fluxes from $\mathrm{EC}^{\mathrm{a}}$ were actually $117 \%$ of $\mathrm{EC}^{\mathrm{b}}$ : this would translate in an overestimation of the cumulative flux when using only central hours of the day values compared to all values through the day. Although there was no clear diurnal pattern in our EC $\mathrm{N}_{2} \mathrm{O}$ fluxes, late-morning fluxes were evidently larger than daily averages. The lack of a diurnal cycle in our study prevents the introduction of a correction factor to account for diurnal variability if cumulative fluxes are calculated based on one singular measurement obtained by manual chambers. However, missed short timescale events will still introduce an error leading to potential over or underestimation.

Cumulative fluxes derived from non-gap-filled chamber measurement data are smaller $(84 \%)$ than the ones derived from gap-filled data. This shows that the integration method can introduce a bias in the estimate of cumulative fluxes and therefore emission factors. In theory the arithmetic mean of a flux dataset provides an actual integration over time. However, if large fluxes are measured only for a short term, e.g. after $\mathrm{N}$ applications, peak values may be over represented, leading to a biased cumulative flux. Indeed chambers data from our comparison periods showed a positively skewed distribution due to large flux values immediately after $\mathrm{N}$ application, with the exception of June 2003, where the data distribution was negatively skewed due to large negative fluxes. EC fluxes overall led to smaller cumulative estimates when compared to chambers, but the values were actually higher in the lower range of emission, and lower in the higher range. A possible explanation for the high-end of the emission range would be the sampling of hot spots of emissions by chambers that get smoothed by the EC integration over a larger surface.

Different measurement techniques used on the same field at the same time, lead to emission factor estimates that can be considerably different: if we take for example the data set from March 2007, we find that EFs from EC and chambers would differ by more than a factor 2 , and using the same technique but different integrating protocols $\left(\mathrm{EC}^{\mathrm{c}}, \mathrm{EC}^{\mathrm{a}}\right)$ leads to a difference of more than $10 \%$. Therefore we think it would be advisable to have a common protocol for integrating cumulative fluxes for whichever method is used to assess the cumulative fluxes, to reduce the uncertainty of IPCC emission factors.

\section{Conclusions}

In this study, $\mathrm{N}_{2} \mathrm{O}$ EC fluxes were mostly ( $70 \%$ of the time) within the range of chamber fluxes. During different comparison periods, EC measured either larger or smaller fluxes compared to the average flux derived from the chambers. One reason for this inconsistency observed on the same experimental field during different comparison periods is partly explained by the possibility that the chosen chambers were not always within the footprint of the EC measurement and therefore measured a different part of the field. The EC method integrates fluxes over a much larger area $(0.01-$ $\left.1 \mathrm{~km}^{2}\right)$ than chambers $\left(<2 \mathrm{~m}^{2}\right.$, all together). High fluxes measured by chambers can represent hotspots, which do not show in the integrative approach of the EC method. Conversely, the EC flux may include large emissions from specific areas where no chambers are sited. The information given by an EC dataset allows a detailed description of the behaviour of a field as a source or sink for $\mathrm{N}_{2} \mathrm{O}$, as it provides high time resolution measurements, showing short time scale events as well as longer ones. However, the current detection limits of the EC fluxes prevent a complete understanding of the soil uptake processes at the field scale. We recommend therefore that the two methods are used in a complementary fashion, to gather overall emission from EC, and spatial knowledge from chambers: for these, high spatial replication would assess the heterogeneity of the $\mathrm{N}_{2} \mathrm{O}$ source. Diurnal variability can be established either by micrometeorological measurements or by the use of autochambers, sampling several times a day when wanting to investigate exchange processes in more detail.

The errors in the estimates of emission factors reflect the uncertainties occurring at different levels:

1. the measurement level: different techniques, or often same technique but following different measurement protocols

2. data quality control level: different standards are used, leading to qualitatively different information following different rejection criteria

3. data analysis level: averaging protocols over the data, leading to different cumulative fluxes.

For these reasons, we think it is paramount at this stage to assess defined protocols in the scientific community, to reduce the uncertainty on emission factors and estimates of national and global $\mathrm{N}_{2} \mathrm{O}$ emission inventories.

Acknowledgements. The authors gratefully acknowledge funding from the EU through the NitroEurope Integrated Project (contract 017841) and the GREENGRASS project (EC EVK"-CT200100105). 
We would like to thank Chris Flechard and Albrecht Neftel for their precious input which greatly contributed to the improvement of this paper.

\section{Edited by: F. Keppler}

\section{References}

Affre, C., Lopez, A., Carrara, A., Druilhet, A., and Fontan, J.: The analysis of energy and ozone flux data from the LANDES experiment, Atmos. Environ., 34, 803-821, 2000.

Ammann, C., Brunner, A., Spirig, C., and Neftel, A.: Technical note: Water vapour concentration and flux measurements with PTR-MS, Atmos. Chem. Phys., 6, 4643-4651, doi:10.5194/acp6-4643-2006, 2006.

Ambus, P. and Christensen, S.: Measurement of $\mathrm{N}_{2} \mathrm{O}$ emission from a fertilised grassland: an analysis of spatial variability, J. Geophys. Res. 99, 16549-16555, 1994.

Aubinet, M., Grelle, A., Ibrom, A., Rannik, Ü., Moncrieff, J., Foken, T., Kowalski, A. S., Martin, P. H., Berbigier, P., Bernhofer, C., Clement, R., Elbers, J., Granier, A., Grunwald, T., Morgenstern, K., Pilegaard, K., Rebmann, C., Snijders, W., Valentini, R., and Vesala, T.: Estimates of the annual net carbon and water exchange of forests: The EUROFLUX methodology, Adv. Ecol. Res., 30, 113-175, 2000.

Bouwman, A. F.: Direct emission of nitrous oxide from agricultural soils, Nutr. Cycl. Agroecosys., 46, 53-70, 1996.

Bremner, J. M.: Sources of nitrous oxide in soils, Nutr. Cycl. Agroecosys., 49, 7-16, 1997.

Chapuis-Lardy, L., Wrage, N., Metay, A., Chottes, J.-L., and Bernoux M.: Soils, a sink for $\mathrm{N}_{2} \mathrm{O}$ ? A review, Global Change Biol., 13, 1-17, 2006.

Christiansen, J. R., Korhonen, J. F. J., Juszczak, R., Giebels, M., and Pihlatie, M.: "Assessing the effects of chamber placement, manual sampling and headspace mixing on $\mathrm{CH}_{4}$ fluxes in a laboratory experiment." Plant and Soil 343, no. 1-2 (6 January 2011): 171-185, available at: http://www.springerlink.com/ index/10.1007/s11104-010-0701-y, 2011.

Christensen, S., Ambus, P., Arah, J. R., Clayton, H., Galle, B., Griffith, D. W. T., Hargreaves, K. J., Klemedtsson, L., Lind, A.-M., Maag, M., Scott, A., Skiba, U., Smith, K. A., Welling, M., and Wienhold, F. G.: Nitrous oxide emissions from an agricultural field: comparison between measurements by flux chamber and micrometeorological techniques, Atmos. Environ., 30, 4183-4190, 1996.

Clayton, H., Arah, J. R. M., and Smith, K. A.: Measurement of nitrous oxide emissions from fertilized grassland using closed chambers, J. Geophys. Res. 99, 16599-16607, 1994.

Clayton, H., McTaggart, I. P., Parker, J., Swan, L., and Smith, K. A.: Nitrous oxide emissions from fertilised grassland: a 2-year study of the effects of $\mathrm{N}$ fertiliser form and environmental conditions, Biol. Fert. Soil., 25, 252-260, 1997.

Crooke, W. M. and Simpson, W. E.: Determination of ammonium in Kjeldahl digests of crops by an automated procedure, J. Sci. Food Agric. 22, 9-10, 1971.

Dämmgen, U., Grünhage, L., and Schaaf, S.: The precision and spatial variability of some meteorological parameters needed to determine vertical fluxes of air constituents, Landbauforschung Volkenrode, 55, 29-37, 2005.
Davidson, E. A.: Fluxes of nitrous oxide and nitric oxide from terrestrial ecosystems, in: Microbial production and consumption of greenhouse gases: methane, nitrous oxides and halomethanes, edited by: Rogers, J. E. and Whitman, W. B., Am. Soc. Microbiol., Washington DC, 219-235, 1991.

Davidson, E. A., Savage, K., Verchot L. V., and Navarro, R.: Minimizing artifacts and biases in chamber-based measurements of soil respiration, Agr. Forest Meteorol., 113, 21-37, 2002.

Desjardins, R. L.: The impact of management strategies in agriculture and agroforestry to mitigate greenhouse gas emissions, in: Management Strategies in Agriculture, Forestry for Mitigation of Greenhouse Gas Emissions, Adaptation to Climate Variability, Climate Change, WMO No. 969. Technical Note No. 202, 30-40, 2004.

Desjardins, R. L., Pattey, E., Smith, W. N., Worth, D., Grant, B., Srinivasan, R., MacPherson, J. I., and Mauder, M.: Multiscale estimates of $\mathrm{N}_{2} \mathrm{O}$ emissions from agricultural lands, Agr. Forest Meteorol., 150, 817-824, 2010.

Di Marco, C.: Temporal and spatial variations of nitrous oxide fluxes in Great Britain., PhD Thesis, Edinburgh University, UK, 2005.

Di Marco, C., Skiba, U., Weston, K., Hargreaves, K., and Fowler, D.: Field scale $\mathrm{N}_{2} \mathrm{O}$ flux measurements from grassland using eddy covariance, Water Air Soil. Poll., Focus, 4, 143-149, 2004.

Dobbie, K. E., McTaggart, I. P., and Smith, K. A.: Nitrous oxide emissions from intensive agricultural systems: Variations between crops and seasons, key driving variables, and mean emission factors, J. Geophys. Res., 104, 26891-26899, 1999.

Du, R., Lu, D., and Wang, G.: Diurnal, seasonal, and inter-annual variations of $\mathrm{N}_{2} \mathrm{O}$ fluxes from native semi-arid grassland soils of inner Mongolia, Soil Biol. Biochem., 38, 3474-3482, 2006.

Flechard, C. R., Neftel, A., Jocher, M., and Ammann, C.: Bidirectional soil-atmosphere $\mathrm{N}_{2} \mathrm{O}$ exchange over two mown grassland systems with contrasting management practices, Global Change Biol., 11, 2114-2127, 2005.

Flechard, C. R., Ambus, P., Skiba, U., Rees, R. M., Hensen, A., van Amstel, A., van den Pol-van Dasselaar, A., Soussana, J.-F., Jones, M., Clifton-Brown, J., Raschi, A., Horvath, L., Neftel, A., Jocher, M., Ammann, C., Leifeld, J., Fuhrer, J., Calanca, P., Thalman, E., Pilegaard, K., Di Marco, C., Campbell, C., Nemitz, E., Hargreaves, K. J., Levy, P. E., Ball, B. C., Jones, S. K., van de Bulk, W. C. M., Groot, T., Blom, M., Domingues, R., Kasper, G., Allard, V., Ceschia, E., Cellier, P., Laville, P., Henault, C., Bizouard, F., Abdalla, M., Williams, M., Baronti, S., Berretti, F., and Grosz, B.: Effects of climate and management intensity on nitrous oxide emissions in grassland systems across Europe, Agr. Ecosyst. Environ., 121, 135-152, 2007.

Fowler, D., Hargreaves, K. J., Skiba, U., Zahniser, M. S., Moncrieff, J. B., Beverland, I. J., and Gallagher, M. W.: Measurements of $\mathrm{CH}_{4}$ and $\mathrm{N}_{2} \mathrm{O}$ fluxes at the landscape scale using micrometeorological methods, Philos. T. Roy. Soc. Lond., 351, 339-356, 1995.

Granli, T. and Bockman, O. C.: Nitrous oxide from agriculture, Norwegian Journal of Agricultural Science Supplement, 12, 128 pp., 1994.

Grant, R. F. and Pattey, E.: Modelling variability in $\mathrm{N}_{2} \mathrm{O}$ emissions from fertilized agricultural fields, Soil Biol. Biochem., 35, 225243, 2003.

Henriksen, H. and Selmer-Olsen, A. A.: Automatic methods for determining nitrate and nitrite in water and soil extracts, Analyst, 
95, 514-518, 1970.

Hojberg, O., Revsbech, N. P., and Tiedje, J. M.: Denitrification in soil aggregates analysed with microsensors for nitrous oxide and oxygen, Soil Sci. Soc. Am. J., 58, 1691-1698, 1994.

Horst, T. W.: A simple formula for attenuation of eddy fluxes measured with first-order-response scalar sensors, Bound.-Lay. Meteorol., 82, 219-233, 1997

IPCC: Houghton, J. T., Meira Filho, L. G., Lim, K., Trennton, I., Mamaty, I., Bonduki, Y., Griggs, D. J., and Callander, B. A. (Eds.): Revised 1996 IPCC Guidelines for National Greenhouse Gas Inventories, Vol. 1-3, 1997.

IPCC: Climate Change 2001, The Scientific Basis - Contribution of Working Group I to the Third Assessment Report of the Intergovernmental Panel on climate Change (IPCC), Cambridge University Press, Cambridge, 2001.

Jones, S. K., Rees, R. M., Skiba, U. M., and Ball, B. C.: Influence of organic and mineral $\mathrm{N}$ fertiliser on $\mathrm{N}_{2} \mathrm{O}$ fluxes from a temperate grassland, Agr. Ecosyst. Environ., 121, 74-83, 2007.

Kaimal, J. C. and Finnigan, J. J.: Atmospheric Boundary Layer flows, Oxford University Press, New York, Oxford, 2nd Edn, 1994.

Kaimal, J. C. and Gaynor, J. E.: Another look at sonic anemometry. Bound.-Lay. Meteorol., 56, 401-410, 1991.

Kroon, P. S., Hensen, A., Jonker, H. J. J., Ouwersloot, H. G., Vermeulen, A. T., and Bosveld, F. C.: Uncertainties in eddy covariance flux measurements assessed from $\mathrm{CH}_{4}$ and $\mathrm{N}_{2} \mathrm{O}$ observations, Agr. Ecosyst. Environ., 150, 806-816, 2010.

Laville, P., H'enault, C., Renault, P., Cellier, P., Oriol, A., Devis, X., Flura, D., and Germon, J. C.: Field comparison of nitrous oxide emission measurements using micrometeorological and chamber methods, Agronomie, 17, 375-388, 1997.

Laville, P., Jamber, C., Cellier, P., and Delmas R.: Nitrous oxide fluxes from a fertilised maize crop using micrometeorological and chamber methods, Agric. Forest. Meteorol., 96, 19-38, 1999.

Leahy, P., Kiely, G., and Scanlon, T. M.: Managed grasslands: A greenhouse gas sink or source?, Geophys. Res. Lett., 31, L20507, doi:10.1029/2004GL021161, 2004.

Lessard, R., Rochette, P., Gregorich, E. G., Pattey, E., and Desjardins, R. L.: Nitrous oxide fluxes from manure amended soil under maize, J. Environ. Qual., 25, 1371-1377, 1996.

Milford, C., Theobald, M. R., Nemitz, E., and Sutton M. A.: Dynamics of ammonia exchange in response to cutting and fertilizing in an intensively-managed grassland, Water Air Soil Pollut. Focus, 1, 167-176, 2001.

Moore, C. J.: Frequency response corrections for eddy correlation systems, Bound.-Lay. Meteorol., 37, 17-35, 1986.

Neftel, A., Flechard, C., Ammann, C., Conen, F., Emmenegger, L., and Zeyer, K.: Experimental assessment of $\mathrm{N}_{2} \mathrm{O}$ background fluxes in grassland systems, Tellus B, 59, 470-482, 2007.

Neftel, A., Spirig, C., and Ammann, C.: Application and test of a simple tool for operational footprint evaluations, Environ. Pollut., 152, 644-652, 2008.

Neftel, A., Ammann, C., Fischer, C., Spirig, C., Conen, F., Emmenegger, L., Tuzson, B., and Wahlen, S.: $\mathrm{N}_{2} \mathrm{O}$ exchange over managed grassland: Application of a quantum cascade laser spectrometer for micrometeorological flux measurements, Agr. Forest Meteorol., 150, 775-785, 2010.

Nemitz, E., Hargreaves, K. J., Neftel, A., Loubet, B., Cellier, P.,
Dorsey, J. R., Flynn, M., Hensen, A., Weidinger, T., Meszaros, R., Horvath, L., Dmmgen, U., Frühauf, C., Löpmeier, F. J., Gallagher, M. W., and Sutton, M. A.: Intercomparison and assessment of turbulent and physiological exchange parameters of grassland, Biogeosciences, 6, 1445-1466, doi:10.5194/bg-61445-2009, 2009.

Pattey, E., Strachan, I., Desjardins, R., Edwards, G., Dow, D., and Macpherson, J.: Application of a tunable diode laser to the measurement of $\mathrm{CH}_{4}$ and $\mathrm{N}_{2} \mathrm{O}$ fluxes from field to landscape scale using several micrometeorological techniques, Agr. Forest Meteorol., 136, 222-236, 2006.

Pumpanen, J., Kolari, P., Ilvesniemi, H., Minkkinen, K., Vesala, T., Niinistö, S., Lohila, A., Larmola, T., Morero, M., Pihlatie, M., Janssens, I., Yuste, J.C., Grünzweig, J. M., Reth, S., Subke, J., Savage, K., Kutsch, W., Østreng, G., Zieglerm, W., Anthonim P., Lindroth A., and Hari, P.: Comparison of different chamber techniques for measuring soil $\mathrm{CO}_{2}$ efflux, Agr. Forest Meteorol., 123, 159-176, 2004.

Pihlatie, M., Rinne, J., Ambus, P., Pilegaard, K., Dorsey, J. R., Rannik, Ü., Markkanen, T., Launiainen, S., and Vesala, T.: Nitrous oxide emissions from a beech forest floor measured by eddy covariance and soil enclosure techniques, Biogeosciences, 2, 377387, doi:10.5194/bg-2-377-2005, 2005.

Ruser, R., Flessa, H., Schilling, R., Steindl, H., and Beese F.: Soil compaction and fertilisation effects on nitrous oxide and methane fluxes in potato fields, Soil Sci. Soc. Am. J., 62, 1587-1595, 1998.

Ruser, R., Flessa, H., Russow, R., Schmidt, G., Buegger, F., and Munch, J. C.: Emission of $\mathrm{N}_{2} \mathrm{O}, \mathrm{N}_{2}$ and $\mathrm{CO}_{2}$ from soil fertilized with nitrate: effect of compaction, soil moisture and rewetting, Soil Biol. Biochem., 38, 263-274, 2006.

Ryden, J. C.: Nitrous oxide exchange between a grassland soil and the atmosphere, Nature, 292, 235-237, 1981.

Scottish Agricultural College: Farm management handbook (Chadwick, L., Edn), SAC, Edinburgh, 16th Ed, 1995.

Simek, M., Brucek, P., Hynst, J., Uhlirova, E., and Petersen, S. O.: Effects of excretal returns and soil compaction on nitrous oxide emissions from a cattle overwintering area, Agr. Ecosyst. Environ., 112, 186-191, 2006.

Skiba, U., Hargreaves, K. J., Beverland, I. J., O’Neill, D. H., Fowler, D., and Moncrieff, J. B.: Measurement of field scale N2O emission fluxes from a wheat crop using micrometeorological techniques, Plant Soil, 181, 139-144, doi:10.1007/BF00011300, 1996.

Skiba, U., Sheppard, L. J., MacDonald, J., and Fowler, D.: Some key environmental variables controling nitrous oxide emissions from agricultural and semi-natural soils in Scotland, Atmos. Environ., 32, 3311-3320, 1998.

Skiba, U. and Smith, K. A.: The control of nitrous oxide emissions from agricultural and natural soils, Chemosphere, 2, 379-386, 2000.

Smith, K. A., Clayton, H., Arah, J. R. M., Christensen, S., Ambus, P., Fowler, D., Hargreaves, K. J., Skiba, U., Harris, G. W., Wienhold, F. G., Klemedtsson, L., and Galle, B.: Micrometeorological and chamber methods for measurement of nitrous oxide fluxes between soils and the atmosphere: Overview and conclusion, Geophys. Res., 99, 16541-16548, 1994.

Smith, K. A., Thomson P. E., Clayton, H., McTaggart I. P., and Conen, F.: Effects of temperature, water content and nitrogen fertil- 
isation on emissions of nitrous oxide by soils, Atmos. Environ., 32, 3301-3309, 1998.

Stull, R. B.: An introduction to boundary layer meteorology, Kluwer Academic Publishers, Dordrecht, 1988.

Taipale, R., Ruuskanen, T. M., and Rinne, J.: Lag time determination in DEC measurements with PTR-MS, Atmos. Meas. Tech., 3, 853-862, doi:10.5194/amt-3-853-2010, 2010.

Velthof, G. L., Brader A. B, and Oenema O.: Effects of nitrogen fertilization and grazing on the emission of nitrous oxide from grassland, in: Climate Change Research: Evaluation and Policy Implications, edited by: Zwerver, S., van Rompaey, R. S. A. R., Kok, M. T. J., and Berk, M. M., Elsevier Science B.V., 627-630, 1995.

Velthof, G. L., Jarvis, S. C., Stein, A., Allen, A. G., and Oenema O.: Spatial variability of nitrous oxide fluxes in mown and grazed grasslands on a poorly drained clay soil, Soil Biol. Biochem., 28, 1215-1225, 1996.

Vinther, F.: Temperature and dentrification, In Danish Report no. A93, National Agency of Environmental Protection, Copenhagen, 1990.
Webb, E. K., Pearman, G. I., and Leuning, R.: Correction of flux measurements for density effects due to heat and water-vapor transfer, Q. J. Roy. Meteorol. Soc., 106, 85-100, 1980.

Wienhold, F. G., Frahm, H., and Harris, G. W.: "Measurements of $\mathrm{N}_{2} 0$ fluxes from fertilized grassland using a fast response tunable diode laser spectrometer," J. Geophys. Res., 99, 16557-16567, March, 1994.

Wienhold, F. G., Welling, M., and Harris, G. W.: Micrometeorological measurement and source region analysis of nitrous oxide fluxes from an agricultural soil, Atmos. Environ., 29, 2219-2227, 1995.

Zahniser, M. S., Nelson, D. D., McManus, J. B., and Kebabian, P. L.: Measurements of trace gas fluxes using tunable diode laser spectroscopy, Exchange of Trace Gases Between Land and Atmosphere, Philos. T. Roy. Soc., 351, 371-382, 1995. 